\title{
Transcendence Dimensions in the Novel Merindu Baginda Nabi by Habiburrahman El Shirazy
}

\author{
Muhamad Fajar Novala, Suyitno, Raheni Suhita
}

Master of Indonesian Language Education, Sebelas Maret University, Surakarta, Indonesia

\begin{abstract}
This study aims to describe and explain the transcendent dimension in the novel Merindu Baginda Nabi by Habiburrahman El Shirazy. The method used in this research is descriptive qualitative method. The data source in this research is the novel Merindu Baginda Nabi. Data collection techniques in this study using documentation study techniques. The validity of the data in this study used the theoretical triangulation technique. The data analysis technique in this study used interactive data analysis techniques. The results of the study found that there are three forms of transcendence found in the novel, namely the recognition of human dependence on God, there is an absolute difference between God and humans, the recognition of absolute norms from God that do not come from human reason. The results of this research can be used as references in the field of literature, especially with regard to the prophetic dimensions that exist in a literary work, and become a contribution to knowledge and can be applied in literary studies that are useful for further researchers.
\end{abstract}

Keywoards-Dimensions, Prophetic, Transcendence.

\section{INTRODUCTION}

Literary works can continue to be accepted by the public because they have a reflective nature. This reflective nature provides flexibility as a means for individuals to formulate complex inner experiences into problems that produce a more true meaning and spirit [1].

Literary work as a cultural product is able to meet the needs of society which is produced through a creative and imaginative process of creation. These needs are expressed through persuasive and informative narrative expressions that can influence the reader, especially in fulfilling spiritual or religious life. Literary works in the form of prose and fiction with Islamic nuances have provided a new discourse for the development of Indonesian literature [2]. Through the existence of Islamic literary works, it provides space for writers as an alternative to da'wah by teaching Islamic values and teachings as well as a means of learning for society with a creative process.

Literary work, besides showing its recreational nature and as a cultural product, is also an illuminator capable of bringing people to search for values that can help them to meet the nature of a personable humanity. Literary works have a spiritual content wrapped in ethics. It is the central aspect where the social and transcendental dimensions meet in the creation of literary works. The social dimension refers to the profane human life and the transcendetal dimension refers to a higher purpose of life, culminating in the unseen above.

The main mission of prophetic aesthetics in literary works is to try to touch the innermost feelings of humans with the aim of awakening them to shape religious behavior. Literary works contain literary elements that can be utilized by humans in human life, especially in their development, literary values are not only intended for recreation but are able to provide religious experiences to the reader. This kind of literary work lies between the aesthetic and ethical realm or dogma capable of creating norms with the aid of aesthetics [2]. Based on this, religious norms or guidelines for religious teachings can be found in literary works wrapped in aesthetic values in the form of a series of languages that have beauty and are able to move the human soul as a religious creature. In line with this, aesthetics holds the main key in literary works as beauty and reasoning that uses symbols and can be used by readers [3]

Prophetic literature is one of the tools used to study literary works from a religious or religious perspective, especially those originating from Islam. The emergence of prophetic literature is based on the proliferation of novels with Islamic nuances that raise religious moral content that can be utilized by society as religious beings, stating that 
prophetic literary works try to balance social and spiritual themes that represent human history and prophetic or religious values with consider aesthetic elements [3]. The beauty of prophetic literature lies in its function, which is to develop the human mind and generate human and divine awareness [4].

Religious values in prophetic literary works contain divine elements in the social and transcendental dimensions. Prophetic literature was re-proclaimed by Kuntowijoyo with views that were more acceptable to society as contained in literary works. The prophetic aspects found through Surah Al-Imran verse 110 are then capitalized into three aspects, namely amar ma'ruf in the form of humanization (calling for goodness), nahi munkar in the form of liberation (preventing evil), and tu'minuna billah in the form of transcendence (believing in God) [5].

The aspect of transcendence is the most important component in shaping personality and individuals as religious beings who believe in the existence and power of God. The source of the discovery of human identity again led to the growth of transcendental possibilities [2]. Transcendence actually does not only include aspects of divinity in the religious sphere, but is also a self-meaning in order to reach the limits of human knowledge and abilities, so that they are more aware of their existence materially.

The transcendental element in prophetic literature is in the form of expressing human consciousness as a religious creature. The element of transcendence is divided into three parts, namely recognition of human dependence on God, there are absolute differences between God and humans, and recognition of absolute norms from God that do not come from human reason [6].

Islamic novels have become popular in Indonesia, some of which have even become a phenomenon in society. Denotative religious language elements that make it easier for readers and provide transcendent experiences in religion. However, nowadays writers are increasingly competing to be able to take advantage of creative language so as to be able to create connotative language in conveying ideas. The writers of Islamic nuances novels are formed in one forum or organization, namely the Lingkar Pena Forum. This organization aims to raise the level of creativity of writers in order to produce quality literary works not only in terms of moral content but through a competent language perspective.

One of the novels with Islamic nuances written by a member of the Lingkar Pena Forum as well as the number one novelist in Southeast Asia, namely Habiburrahman El Shirazy, is the novel Merindu Baginda Nabi which was successfully made into a big screen film in 2018 and is selling well in the market. The novel Merindu Baginda Nabi is a novel that can bring sad and sweet situations together at the same time, able to be a solution to life's problems through its characters.

Based on this explanation, it is interesting to study how prophetic in the aspect of transcendence as the main marker of Islamic literature contained in the novel Merindu Baginda Nabi by Habiburrahman El Shirazy. How the disclosure of the transcendent aspect as a prophetic reality that is connected with the existence of modern human reality as a religious being.

\section{METHOD}

This research is a qualitative descriptive type. Qualitative descriptive is a type of research that describes data in the form of words, phrases, clauses, and sentences instead of numeric data [7]. The method used to study the data sources used a prophetic literary approach. The data in this study were the prophetic dimensions of transcendence in the novel Merindu Baginda Nabi. The data source in this study is the novel Merindu Baginda Nabi by Habiburrahman El Shirazy. Data collection techniques in this study using documentation study techniques. Documentation study is the activity of recording documents related to research objectives [8]. The data validity technique in this study used theoretical triangulation. Data analysis techniques in research using interactive data analysis techniques.

\section{RESULTS AND DISCUSSION}

In accordance with the results of the research, this section will explain the discussion of the transcendence prophetic dimension contained in the novel Merindu Baginda Nabi by Habiburrahman El Shirazy. The discussion presented includes three aspects (a) recognition of human dependence on God, (b) there is an absolute difference between God and man, and (c) recognition of absolute norms from God that do not come from human reason.

\section{Confession about human dependence on God}

Humans basically have a dependence on God, because only God has power over all human life both in relation to God and with fellow humans. In the novel Merindu Baginda Nabi expresses recognition of human dependence on God which is expressed in language that contains aesthetic elements, as follows.

"Ah kini ia semakin biasa menghayati dunia ini kecil. Alam semesta yang luas ini juga kecil dibandingkan 
kekuasaan Allah yang tiada terbatas besarnya. Kalua Allah berkehendak, maka terjadi begitu saja, dan taka da yang bias menghalanginy. Jujur. Ia tidak pernah bermimpi seperti yang baru saja ia alami dan masih ia alami. Tapi ketika Allah menghendaki dirinya sampai di Amerika, terjadi begitu saja dengan mudahnya. Sebab-musababnya Allah datangkan dari jalan yang sama sekali tidak pernah ia sangka." (Shirazy, 2018:7)

"Ah, now he is getting used to living this small world. This vast universe is also small compared to Allah's infinite power. If Allah wants it, it just happens, and nothing can stop it. Honest. He never dreamed like he had just experienced and he still does. But when God wanted him to arrive in America, it just happened. The reasons for Allah's coming from a way that he never expected." (Shirazy, 2018:7)

The transcendent aspect as an acknowledgment of human dependence on God can be found in the above quotation. Through the data quotation above, it is known that humans as creatures who believe in and trust in the power and existence of God put all their affairs and submit themselves to God in relation to their life on this earth. Prophetic literary work seeks to express human phenomena with aesthetic values and to present humans to always remember God, remind human existence before God and human willingness to accept God's guidance [9], [10]. "Humans naturally surrender and fully trust all their destiny and life to Allah because of the belief in religious creatures that Allah is able to control all human situations and conditions with the best plan, as experienced by the main character named Rifa in the quote above for eight months Rifa felt beauty and beauty because of getting new experiences in the country of people. The beauty and pleasure she had never imagined before, but he realized that even though everything was beyond his expectations there was a God with all its possibilities Rifa always implied that everything, movement or action boils down to His God" The form of human dependence on God is also expressed in other quotes, as follows.

"Rifa memulai slidenya dengan tulisan Arab berbunyi Bismillahirrahmanirrahim

Tanpa dimulai dengan bismillah segala amal baik jadi sia-sia. Abah dan Ummi saya mengajari itu sejak kecil. Ini doa paling mudah dan paling ampuh yang bisa kita amalkan untuk semua aktivitas positif. Dan ketika memutuskan daftar pertukaran pelajar ke Amerika, lafaz inilah yang saya ucapkan," (Shirazy, 2018:43)

"Rifa started her slide with Arabic script reading Bismillahirrahmanirrahim
Without starting with bismillah all good deeds are in vain. My Abah and Ummi taught me since childhood. This is the easiest and most powerful prayer we can practice for all positive activities. And when deciding on a student exchange list to America, this lafaz is what I say," (Shirazy, 2018:43)

The data quotation above shows that humans in their life on earth always have troubles and problems. In solving problems, humans must always involve Allah in order to find the best solution. Therefore humans often say prayers, ask for help, ask for protection, and so on, all of which are addressed to Allah. As did the main character named Rifa, she always involves Allah in all her affairs by reading bismillah when she wants to start something or solve a problem. Through the data quotation above, it illustrates that Allah always hears requests, complaints, help and even forgiveness.

Through the nature of hearing or As Samii has been widely expressed in the Qur'an Asy Syrura verse 11 which means: "There is nothing like Him, and it is He who is all hearing, all seeing". The content of this verse means that Allah is able to hear any language near or far, even if it is not spoken. Then Allah also has the power to grant every request, help and even forgiveness of His servants.

The reality of human dependence is a transcendental process presented through symbols in literary works which are expressed from the imagination of the author. Text that contains meaning is often the result of a response to social reality that contains universal messages and transcendental meanings [1]. Based on this, through the above data quotations, the characters in the novel experience awareness of the nature of God who always hears, so that there is a dependence on always talking to God. Through this explanation it can be interpreted that speaking to God can be interpreted as praying or praying, which makes humans. The transcendent aspects contained in the novel are manifested in the following quotations,

\section{“Kenapa menangis Rif?” tanya Pak Nur}

"Ah, nggak apa, Abah, hanya teringat betapa Allah Maha Penyayang. Tadi lewat jalan di mana Rifa jatuh. Kalau Rifa sampai terlindas truk, Rifa sudah tidak lagi hidup di dunia ini. Alhamdulillah, Allah masih beri Rifa napas dan nyawa untuk memperbaiki diri." (Shirazy, 2018: 111).

“Why are you crying Rif?” asked Pak Nur

"Ah, it's okay, Abah, just remembering how Merciful Allah is. Earlier on the road where Rifa fell. If Rifa gets run over by a truck, Rifa will no longer live in this 
world. Alhamdulillah, Allah still gives Rifa breath and life to improve herself." (Shirazy, 2018: 111).

Every creature desires a sense of continuous happiness and joy, while all this can only be given by God. That prolonged feeling of happiness makes humans or other creatures feel addicted to God. This dependence seems to make humans always vying for that pleasure or happiness. While the reciprocity that must be done to God is in the form of acknowledging God by saying His name, remembering himself and not ceasing to love Him. This attitude is in accordance with the data quotation above, that the main character Rifa is very lucky to still be given the opportunity to live a long life because of avoiding death. Then she uttered the lafaz Hamdallah as an expression of her joy.

The data quotation above shows that the transcendent aspects contained in prophetic literature can provide divine awareness to humans. Prophetic literature has the potential to form superior human beings with global insight by balancing the spiritual and social dimensions [1]. Based on this, the transcendent aspect in literary works can provide direction or guidance to make humans aware of their nature on earth, which always depends on God in various aspects of life.

\section{There is an absolute difference between God and Human}

All religious teachings teach mankind that there is a being that has power beyond the limits of human capabilities and has absolute differences, so that humans must have the feeling of obeying and submitting to that essence. In Islam it also states that the entire universe is Allah's creation, so that humans are one of Allah's creatures who must always believe in Him. Through this concept, it is clear that God and humans have absolute differences. This transcendent aspect is also expressed in the novel Merindu Baginda Nabi, which is as follows.

"Fiona lalu begegas ke kamar mandi mengikuti arahan Rifa. Louise memutar video hasil rekamannya di ponsel. Sangat jernih. Suara Fiona mengucapkan dua kalimat syahadat juga sangat jelas. Rifa masih meneteskan air mata. Keharuan itu masih kencang terasa. Ia teringat awal berjumpa dengan Fiona. Segala kenangannya berkerkelebatan begitu saja, termasuk pertanyaan-pertanyaan Fiona tentang islam. Ia tidak menduga sama sekali bahwa Fiona akhirnya diberi hidayah oleh Allah dan masuk islam" (Shirazy, 2018:131)

"Fiona then rushed to the bathroom following Rifa's direction. Louise played the video she recorded on the cellphone. Very clear. The voice of Fiona saying the two sentences of the creed was also very clear. Rifa still had tears in her eyes. The compassion was still strong. She remembered the first time she met Fiona. All her memories flashed like that, including Fiona's questions about Islam. She did not suspect that Fiona was finally given guidance by Allah and converted to Islam" (Shirazy,2018:131).

Through the quotation from the data story above, it is illustrated that Allah has the power so that he can do anything in the world. Humans as Allah's creatures do not need to anxious and worry about the destiny and decrees that Allah has planned, because thanks to unwavering faith it will produce positive and good results. Allah has absolute control over human life. As in the quote above, Fiona, a friend of Rifa, received guidance to embrace Islam. It is clear that Fiona's entry to Islam was solely due to the power and decree (destiny) of Allah SWT. Because destiny can be said to be one of the attributes of Allah who is able to do whatever He wants, because the position of human in the world and the hereafter depends on Allah's decree before humans are born into this world [11].Based on this explanation, it is clear that God and human have absolute differences, namely as a creator and a created being. In other data, it is also disclosed about the absolute difference between God and human, the quotation of the data is as follows.

"Rifa dan seluruh pengurus pesantren Darus Sakinah. Abah wafat satu jam yang lalu usai shalat Ashar di Masjis Nabawi/ abah sowan Baginda Nabi dan tidak boleh pulang kembali. Abah husnul khotimah, amiin, aamiin, aamiin. Insya Allah, besok Abah di makamkan di Baqi bersama para sahabat Nabi SAW. Kalian jangan sedih, karena Abah bahagia selama sowan Baginda Nabi SAW." (Shirazy, 2018:161)

"Rifa and all the board of the Darus Sakinah pesantren. Abah died an hour ago after the Asr prayer at Masjis Nabawi / Abah visited the Prophet and was not allowed to return home. Abah husnul khotimah, amen, aamiin, aamiin. God willing, tomorrow Abah will be buried in Baqi with the companions of the Prophet SAW. Don't be sad, because Abah was happy while visiting the Prophet SAW." (Shirazy, 2018:161)

God has absolute differences with humans, especially in terms of creation. As religious creatures, humans must believe that Allah is the One who created the entire universe and everything in it. The author through the above quotation illustrates that Allah has the ability to be the regulator and creator of humans with all the provisions and the best destiny for humans. Human destiny is in the form of the above quote that the character Pak Nur died in 
Medina while performing the Umrah worship. This shows that it is all a decree (destiny) from Allah SWT. All human destiny has been recorded in lauhl mahfuz whichwill not change, except by the will of Allah [12].

Humans are endowed with a mind that functions to learn things related to life support, so that they differentiate from other creatures on earth. However, human reason is limited by reasoning that is only material in nature, meaning that some intangible things are sometimes unable to reason properly and are even considered impossible. The quote in the novel Merindu Baginda Nabi which contains aspects of acknowledging God's norms which do not originate from human reason are as follows.

"Ibu akan pergi tapi kalian jangan sedih dan jangan memikirkan ibu. Pikirkan diri kalian yang tidak lama lagi akan ujian nasional. Alhamdulillah ibu sudah mendapat tawaran menjadi dosen di perguruan tinggi islam swasta paling besar di kota ini. Ibu diminta jadi dosen matematika. Insya Allah tidak ada masalah bagi ibu. Ibu malah berfikir untuk lanjut s3 di luar negerisetelah dapat nomor induk dosen nanti.orang yang memfitnah ibu tidak bisa mencabut ilmu yang dikaruniakan oleh Allah dari Ibu”. (Shirazy,2018:89)

"Mother will go but you guys don't be sad and don't think about mother. Think of yourself who will soon be going to the national exam. Alhamdulillah, mother has received an offer to become a lecturer at the largest private Islamic college in this city. Mother was asked to be a math lecturer. Insya Allah, there is no problem for the mother. Mother instead thought of continuing s3 abroad after getting the teacher's ID number later. People who slander you cannot take away the knowledge that Allah has given you from you." (Shirazy,2018:89).

The quotation from the data story above can be interpreted as the process of answering human prayers as a form of love from God. Allah gives love to humans in unique ways, some with things that are happy, sad or painful. It all started from the absolute provision of Allah that humans could not instinctively understand, because in essence God knows what is best for His creatures. The author, in his writing style, expresses the fortunes and tests that humans get through sad and painful things, namely through the character Bu Ririn who is slandered by someone, until she is expelled from her job as a teacher. Then Allah returned the pain experienced by Mrs. Ririn due to being slandered with happiness, namely by giving a job change to become a lecturer at one of the largest private Islamic universities in her city. This shows that Allah SWT says to the character Mrs. Ririn by answering the prayers of those who are wronged.

Allah has a generous nature or ar-rahman which is a form of mercy from Allah and is bestowed on certain people with the aim of providing wisdom or forgiveness [11]. This grace is a norm or provision from Allah to all creatures with a specific purpose.

\section{CONCLUSION}

Based on the results of research and discussion, it can be concluded that the transcendent aspect of literary works is a form of human understanding in the face of bimi which cannot be separated from human consciousness where it comes from. Based on research on transcendence aspects in the novel Merindu Baginda Nabi, it reveals three main elements. First, the acknowledgment of human dependence on God which is marked by the aspects of (1) belief and trust in Allah, (2) Allah who is all-hearing, and (3) Allah is all-gracious and most merciful. Secondly, there is an absolute difference between God and humans including aspects, (1) Allah has the power to create the universe and its contents including humans and other creatures, and (2) is able to do anything on earth. The third acknowledgment of the existence of absolute norms from God which do not come from human reason includes aspects, (1) giving mercy to all His creatures.

\section{REFERENCES}

[1] S. Sugiarti, "Kesadaran Ketuhanan Tokoh Utama Dalam Kumpulan Cerpen Ketika Mas Gagah Pergi Dan Kembali Karya Helvy Tiana Rosa," KEMBARA J. Keilmuan Bahasa, Sastra, dan Pengajarannya, vol. 2, no. 1, p. 90, 2017, doi: 10.22219/kembara.vol2.no1.90-97.

[2] Anwar Efendi, "Realitas profetik dalam novel," Litera, vol. 11, no. 1, 2012.

[3] R. Wulananda, D. Saryono, and H. Suwignyo, "Estetika Profetik Novel Muhammad: Lelaki Penggenggam Hujan Karya Tasaro G.K. sebagai Sumber Pendidikan Karakter.," J. Pendidik. - Teor. Penelitian, dan Pengemb., vol. 1, no. 7, pp. 1350-1363, 2016, doi: 10.17977/jp.v1i7.6564.

[4] L. Claassens and M. Juliana, "Human dignity in the prophetic traditions: Upholding human worth in a context of dehumanisation," Nederduitse Geref. Teol. Tydskr., vol. 52, no. 1, pp. 34-44, 2011, doi: 10.5952/52-1-4.

[5] Kuntowijoyo, Maklumat Sastra Profetik, Pertama. Yogyakarta: Diva Press, 2019.

[6] R. Garaudy, "Promesess De I'Islam." SKD Bavaria, Munchen, 2000.

[7] Mattew B Miles and Michaeil Hubermen, Analisis Data Kualitatif Terj. Tjejep Rohidi. Jakarta: Ui Press, 1992.

[8] J. W Creswell, Research design: Qualitative, quantitative, and mixed methods approaches. United States: SAGE 
Publications, Inc, 2009.

[9] Y. Desiana and M. F. Munaris, "Nilai-Nilai Realitas Profetik Novel Bulan Terbelah Di Langit Amerika dan Pengembangan," J-Simbol, pp. 1-10, 2017.

[10] Abdul Hadi W. M, Hermeneutika, Estetika, dan Religiusitas Esai-esao Sastra Sufisti dan Seni Rupa. Yogyakarta: Matahari, 2004.

[11] Haryadi, "Syair Perahu I," vol. 11, no. 2, pp. 243-255, 2012.

[12] Y. P. Sulidar, Ardiansyah, "Wawasan Tentang Taqdir Dalam. J. Hadith Stud., vol. 1, no. 2, p. 16, 2017. 